\title{
Profitability, Operating Efficiency and Capitalization of the Portuguese Banking System (1992-2009)
}

\author{
MÁRIO COUTINHO DOS SANTOS* \\ CICEE, Portugal
}

To cite this article: Coutinho dos Santos, M. 2021. Which Determinants Matter for Capital Structure? Evidence from Polish and Portuguese Nonfinancial Firms. European Review of Business Economics I(1): 111-145; DOI: https://doi.org/10.26619/ERBE-2021.01.6.

\begin{abstract}
In this article, we conduct an empirical comparative analysis of the Portuguese Banking System (PBS) during the 1993-2009 period. Using a dataset drawn from the Organisation of Economic Cooperation and Development's (OECD) Banking Statistics - the Financial Statements of banks database, we examine the performance, in terms of the profitability, operating efficiency, and the capitalization of the PBS, in comparison to a sample of euro area banking systems. We found concerning profitability that PBS outperformed in terms of ROA, but underperformed relative to ROE. It outperformed in terms of operating and interest income, cost to income, and net interest margin efficiency. It did not perform differently in terms of the efficiency of operating and interest expenses. It was less exposed to liquidity risk, but more exposed to credit risk, and was undertaxed relative to its control sample peers. Bookvalue capital ratios document that the PBS was overcapitalized, but undercapitalized in terms of the regulatory capital ratio.
\end{abstract}

BANKING ORGANIZATIONS ARE DEEMED SPECIAL because of the unique functions they perform in the economy. First and foremost, the supply and the administration of transaction and payment services, the provision of liquidity and credit, and the transmission of monetary policies to the economy (e.g., Crouhy and Galai, 2018; Olson, 2006; Bossone, 2000; Merton, 1995; England, 1991). ${ }^{1}$

These pivotal roles played by banks in most national financial systems are a conspicuous motivation for governments in most countries across the globe to exert supervisory and regulatory discipline over the banking industry (e.g., Freixas and Rochet, 2008; Barth et al., 2001; Dewatripont and Tirole, 1993).

Further, the severity of adverse macroeconomic shocks, such as financial crises, can threaten the safety and the soundness of a banking system, and even the financial stability of a country. The likelihood of such outcomes creates an incentive for governments worldwide to extensively monitor banking conduct and performance, to prevent disruption in the provision of their financial intermediation services; and to mitigate the burden on taxpayers associated with potential negative externalities induced by banks' conduct (e.g., Flannery, 2001, 1994). ${ }^{2}$

* This paper uses the dataset developed for Banking in Portugal's chapter 6 entitled "Performance and Efficiency of the Portuguese Banking System", in Anabela Sérgio, Editor, Palgrave Macmillan Studies in Banking and Financial Institutions, London, UK; DOI: 10.1057/9780230371422_6; C) 2016 Mário Coutinho dos Santos. The author gratefully acknowledges the valuable comments and helpful suggestions of João Pinto, Pedro Duarte Silva, and Victor Mendes, and excellent research assistance from Jorge Mota. Any errors and omissions are the sole responsibility of the author. This research did not receive any specific grant from funding agencies in the public, commercial, or not-for-profit sectors.

\footnotetext{
${ }^{1}$ Throughout the paper, we use the terms bank, banking organization, depository institution, and financial institution interchangeably. All the designations refer to commercial banks, bank holding companies, savings banks and thrifts.

2 Throughout the paper, we use the terms banking system, banking sector and banking industry interchangeably.
} 
Due to those allegedly detrimental externalities, banking organizations are also required to comply with mandatory accounting and financial reporting standards, financial disclosure requirements, and the external auditing of financial statements. However, the pervasive informational opacity of the many financial assets banks typically carry on their balance sheets may hinder efforts in monitoring the economic performance and financial condition of banks.

In these instances, monitoring the different dimensions vis-à-vis the performance of banking systems is a recurring practice among government officials, central bankers, regulatory and supervisory agencies, banking communities, deposit insurers, rating agencies, financial analysts and academic researchers.

In many countries worldwide, banking watchdogs, such as capital adequacy regulators and deposit insurance administrators, engage in extensive bank surveillance to monitor and appraise economic performance, financial condition, and compliance with safety net mechanisms, capital adequacy standards, and deposit insurance provisions. Supervisory and regulatory agencies, for example, also engage in monitoring banking activities to gather information on their individual economic performance and financial condition, aiming at promoting the safety, the soundness and the stability of a banking system as a whole (e.g., Krainer and Lopez, 2002; Sahajwala and Van den Bergh, 2000; Flannery and Houston, 1999; Dahl et al., 1998; Avery, 1997).

It is well-known that in performing their financial intermediation functions, banks gather and process relationship-specific private information on the informationally opaque financial assets they carry on and off their balance sheets. However, those functions may be also helpful in mitigating asymmetric information problems. When screening and monitoring borrowers, banks acquire informational advantages, which themselves become a source of information asymmetry between banks and financial market participants, acting as delegated monitors (e.g., Flannery and Houston, 1999; Lucas and McDonald, 1992; Ross, 1989; Diamond, 1984; Campbell and Kracaw, 1980). ${ }^{3}$

The reason for this practice is twofold. On the one hand, the importance of wellfunctioning, stable, sound and safe banking systems for the financial and economic performance of countries, and to promote growth and social welfare. On the other hand, the need for banks to adequately monitor, not only, their risk-taking behavior, but also the allocative efficiency of the resources they manage. Hence, the examination of bank performance has been given considerable attention, accumulating a large body of theoretical and empirical literature by academics and practitioners in the field (see, e.g., Hughes and Mester, 2010; Degryse et al., 2009; Mester, 2008; Berger and Humphrey, 1997; Berger et al., 1993).

The main purpose of this paper is to investigate the profitability, risk, operating efficiency, and capitalization dimensions of the Portuguese Banking System's (hereafter, PBS) performance, during the 1993-2009 period, in comparison to a sample of euro area countries, using accounting-based metrics. ${ }^{4}$ Our paper, despite

\footnotetext{
3 According to Ross (1989), «loan organizations are opaque», as they only allow market participants a blurred 'view' of their financial assets' true risk and return characteristics. One of the reasons banking firms' assets are characterized by a significant amount of opacity is that «banks know more about the quality of their assets than do outside investors» (Lucas and McDonald, 1992, p. 86). For further details see Iannotta (2006), Flannery et al. (2004), and references therein.

4 Our control sample includes Austria, Belgium, Finland, France, Germany, Greece, Ireland, Italy, Luxembourg, the Netherlands and Spain.
} 
using a dataset drawn from the same database as Albertazzi and Gambacorta (2010, 2009), differentiates from those papers, because it has a more focused scope. For this study, we used a dataset of aggregated financial statements of national banking sectors of Portugal and a control sample of European euro area countries, drawn from the OECD's Banking Statistics - the Financial Statements of banks harmonized database.

The remainder of the paper is organized as follows: the next section describes the background, and parsimoniously reviews the literature. Section II provides details on the empirical implementation, followed by an analysis of the profitability, operating efficiency and capitalization. A summary of findings concludes the paper.

\section{Background and literature review}

\section{A. Snapshot of the Portuguese banking system}

Over the last decades, driven by waves of economic and market integration, financial innovation, deregulation, and technological change, worldwide banking markets and institutions became larger, more complex, more competitive and more interconnected. 5

PBS was not immune to such transformations. Joining the European Economic Community (EEC), the European single market, and the third phase of the Economic and Monetary Union (EMU) were significant catalyzers of major structural readjustments in the economy in general, and in the financial and banking systems in particular. ${ }^{6}$

At the banking system level, Portugal might have been one of the European countries that experienced more pressure for readjusting its competitive and operating banking model. The privatization of formerly nationalized banks, the financial system deregulation trends of the 1980s and 1990s, and the challenges of the European single market for financial services were among the major hurdles faced during this liberalization process. 7

\section{B. Literature review}

Organizational performance measurement has been on the research agenda of both academics and practitioners for decades. As a result, a profusion of performance measurement frameworks and methodologies has been developed and applied (e.g., Bikker and Bos, 2008; Neely et al., 2007; Kennerley and Neely, 2003; Eccles, 1991).

Business performance measurement aims at assessing how an organization is performing in terms of «the efficiency and effectiveness of past (business) action(s)» (Neely et al., 2002). Despite the fact that the approach has well-known caveats, in practice, many organizations use accounting-based performance measures to

5 For comprehensive overviews of the European banking industry spanning a similar time frame see, e.g., Schoenmaker and Peek (2014), Goddard et al. (2007), Dermine (2003), and Murphy (2000).

${ }^{6}$ See Valério (2010) for a comprehensive historical overview of the political economics of the PBS. Borges' (1993) analyses of the integration of the PBS in the European Single Market.

${ }_{7}$ See Appendix I for a summary of the milestones of the modernization process of the PBS, and Appendix II for the chronogram of the Portuguese banks reprivatization program. 
«quantify the efficiency and/or effectiveness of past action(s)» (ibid.), meaning that accounting-based performance indicators exhibit a backward-looking nature. 8

In banking, the examination of the relationship between market structure, performance and efficiency has most often been conducted, under two competing paradigms: the structure-conduct-performance (SCP), and the efficient-structure (EFS) methodological approaches (e.g., Degryse et al. 2009; Berger, 1995; Hannan, 1991).9

A comprehensive branch of the economics literature identified the market structure and conduct, as major determinants of firms' performance. Under the SCP paradigm, the conduct of business firms, namely banks, is determined by the market structure of the industry it integrates, which determines the (random) long-run performance (e.g., Neuberger, 1998, 1997; Scherer and Ross 1990; Schmalensee, 1985; Scherer, 1980; Bain, 1959, 1956). ${ }^{10}$

Under the EFS hypothesis, the technical and allocative efficiency, in addition to economies of scale and scope are the major focus of analysis (Coelli, et al. 2005; Molyneux et al., 1996).

Prior research on Portuguese banking performance and efficiency is relatively exiguous. A parsimonious overview of this literature includes: (i) Martins and Ribeiro's (2013) estimation of a stochastic frontier model, using a non-consolidated panel data for 22 banks operating in Portugal between 1995 and 2001; (ii) Cabrita and Bontis' (2008) examination using partial least squares structural equation modeling of the «... inter-relationships and interactions among intellectual capital components and business performance in the Portuguese banking industry»; (iii) Portela and Thanassoulis' (2007) DEA study of the «links between operational and profit efficiency and also between transactional and operational efficiency»; $i v$ ) Barreto and Baden-Fuller's (2006) research on the "Portuguese bank branching decisions between 1988 and 1996»; $(v)$ Molyneux and Forbes (1995) tested both the structure-conduct-performance (SCP) and the efficiency hypotheses using pooled and annual data of the European banking industry over the 1986-1989 sampling period. Their findings are consistent with SCP in explaining the behavior of a sample of European banks; (vi) Mendes and Rebelo's (2003) empirical examination of «the structure-performance relationship in the Portuguese banking industry during the nineties»; (vii) Canhoto and Dermine's (2003) test of the hypothesis that 'de novo' banks are likely to experience higher levels of operating efficiency than 'established' banks, on a sample of 20 Portuguese domestic banks, over the 1990-1995 sample period; (viii) Coutinho dos Santos' (2003) principal components analysis of a sample of 54 Portuguese banks, using financial statement data published by the Associação Portuguesa de Bancos (APB) for a set of 21 banking performance indicators; ( $i x$ ) Pinho's (2001) estimation of efficiency of the Portuguese banking industry; $(x)$

\footnotetext{
8 This methodological approach ignores the cost of equity capital, it is based on accounting data collected and processed under nonuniversal (changing) accounting principles and practices, and which may be prone to manipulation.

9 For reviews of this literature see, e.g., Hughes and Mester, 2010; Degryse et al., 2009; Bikker and Bos, 2008; Mester, 2008; Berger and Humphrey, 1997; Neuberger, 1998, 1997; Goldberg and Rai, 1996; Molyneux et al., 1996; Molyneux and Forbes, 1995; Berger et al., 1993; Hannan, 1991.

10 Without loss of generality, henceforth, we will use 'market structure' and 'industry structure' interchangeably.
} 
Alpalhão and Pinho's (1990) conduct a ratio analysis of the financial statement data of Portuguese banks over the 1980-1989 period.

Recent research on banking performance in terms of profitability, operating efficiency, and capitalization, outside the Portuguese banking market, include: (i) Ferretti et al. (2012), who analyzed a set of performance indicators using accounting data for a sample of Italian banks over the 1999-2010 sampling period. Their analysis focused on earnings, efficiency, credit risk, capital adequacy, and stock market performance; (ii) Dietrich and Wanzenried (2011), who investigated the profitability of a panel data of 372 commercial Swiss banks over the 1999-2009 period, finding that "profitability is, for the most part, explained by five factors: operational efficiency, the growth of total loans, funding costs, the business model, and the effective tax rate»; (iii) Albertazzi and Gambacorta (2010) used a dataset drawn from the OECD's banking statistics database, over the 1981-2003 sampling period, and included the yearly balance sheet and the income statement data for Austria, Belgium, France, Germany, Italy, the Netherlands, Portugal, Spain, the United Kingdom and the United States, examining «how banks' activity is affected by corporate income tax»; (iv) Goddard et al. (2010), using Bankscope data document substantial variations in the average profitability of banks across different European Union countries, including Portugal, over the 1990-2006 period; $(v)$ Albertazzi and Gambacorta (2009) studied the link between banking profitability and macroeconomic and financial shocks associated with the business cycle, using Albertazzi and Gambacorta's (2010) dataset (as detailed above); (vi) Bikker and Bos (2008), who used a panel data set for 46 countries, including European Union (EU), OECD, Eastern and Central European countries drawn from the BankScope database to conduct an empirical examination of banking performance and efficiency during the 1996-2005 sampling period, using different methodological approaches; (vii) Loukoianova (2008) uses data envelopment analysis (DEA) to analyze the efficiency and profitability of Japanese banks during the 2000-2006 sampling period. Findings document that the overall performance of Japanese banks has been improving since 2001, and profitability is low relative to other advanced countries; (viii) Goddard et al. (2004) examined «determinants of profitability in six major European banking sectors: Denmark, France, Germany, Italy, Spain and the UK, for the 1992-1998 period. Although there are some significant size-profit relationships in some of the estimations, overall the evidence for any consistent or systematic sizeprofitability relationship is unconvincing»; ( $i x$ ) Seabright et al. (2002) examined the performance of a sample of 515 banks in transition economies, using a dataset drawn from the BankScope database for the 1994-1999 sampling period; $(x)$ Lozano-Vivas et al. (2001) using Data Envelopment Analysis (DEA) to examine bank performance and technical efficiency at the European Union level; (xi) Resti's (1997) findings of econometric and linear programming study of a panel of 270 Italian banks suggest that using those two methodological approaches does not yield significantly different results; (xii) Goddard et al. (2004a, b) hypothesize a positive relationship between efficiency and capitalization ratios due to purported capital adequacy regulatory rulings on underperforming banks (see also, Goddard et al., 2010; Kwan and Eisenbeis, 1997); (xiii) Bitar et al. (2018) document vis-à-vis a sample of banks from 
39 OECD countries over the 1999-2013 period that regulatory capital banking capital requirements were effective in improving bank efficiency and profitability, but could fail in curtailing bank risk-taking; (xiv) Petria et al. (2015) found that credit and liquidity risk, management efficiency, business diversification, market concentration, and economic growth are determinants of banking profitability; and $(x v)$ Bouzgarrou et al.'s (2018) research of the profitability of 170 commercial, domestic and foreign banks operating in the French market during the 2000-2012 period. Findings document that «foreign banks are more profitable than domestic banks, especially during the financial crisis».

Theoretical and empirical arguments suggest the presence of a linkage between banks' capitalization and economic activity. For example, in adverse economic downturns, losses in credit portfolios erode banks' capitalization, making risk-based capital adequacy requirements, like an 'automatic stabilizer', procyclical. If banks cannot quickly raise sufficient new capital, their lending capacity will fall, and a credit crunch may follow. However, correcting the potential contractionary effect on credit supply by relaxing capital requirements in difficult times may increase bank failure probabilities precisely when, because of high loan defaults, they are largest. (e.g., Repullo and Suarez, 2013; Meh and Moran, 2010).

Prior research has shown that banking endogenous capitalization is contingent on internal funding generation which, in turn, depends on the bank's levels of profitability, dividend payout, and the size of the growth opportunity set. Therefore, sustained levels of profitability and accommodative dividend policies are key to maintain the stability of banking capitalization. Even when a bank's solvency is high, its weak profitability may impair its capacity to absorb negative shocks, eventually impacting solvency risk. Further, empirical research found that more capitalized banks tend to operate more efficiently, suggesting capitalization condition may be a good performance surrogate (e.g., Durand, 2019; García-Herrero et al., 2009; Goddard et al. 2004; Higgins, 1977).

Banks appear to strive for the growth of the amount of assets they carry, on and off their balance sheets, based on the expectation that growth may drive market power, and ultimately profitability. According to Vasiliou and Karkazis' (2002) modeling, bank's asset base sustainable growth rate (SGR) is driven by the return on assets ratio (net income to net total assets), the retention rate (=1 - dividend payout ratio), and the capital ratio (equity to net total assets). The model sheds lights on the interaction between banking profitability and capitalization to explain banking SGR.

The long-run relationship between bank capitalization and profitability is wellestablished in the literature, suggesting that better capitalized banks tend to be more profitable (e.g., Osborne et al., 2012; Goddard et al., 2010; Goddard et al., 2004a, b; Demirgüç-Kunt and Huizinga, 1999; Kwan and Eisenbeis, 1997; Berger, 1995). For example, Coccorese and Girardone (2020), using bank-level data for a sample of 125 countries over the 2000-2018 period, document the presence of a positive relationship between profitability and capitalization, influenced, among other factors by bank size, and crisis episodes.

Evidence on real-world banking leverage document that banking capital ratios appear to revert towards specific target leverage ratios (e.g., Crouhy and Galai, 2018; DeAngelo and Stulz, 2015; Gropp and Heider, 2010; Berger et al. 2008; Brewer III 
et al., 2008; Flannery and Rangan, 2008).

\section{Empirical implementation}

Banking performance research can be conducted at two levels: (i) at the individual bank level, or groups of banks level; and (ii) at the banking system level.

Despite the availability of cross-sectional data on national banking systems, there is a relative paucity in comparative examinations of the performance of banking systems, compared with the cross-sectional and time-series research using datasets of individual banks. However, researching the performance of a specific banking system, cross-sectionally, using individual bank's datasets, may bias empirical findings, and therefore undermine meaningful comparisons between national banking systems. ${ }^{11}$

As the object of this empirical examination performance is a banking system as a whole, understanding its relative performance compared to its cohorts, tends to be more useful than the analysis of individual banks' financial statements.

In this comparative examination of the PBS performance, we use a dataset drawn from the banking statistics published by the OECD. ${ }^{12}$ These statistics include the aggregated annual financial statements for the banking sectors of OECD member countries, harmonized to mitigate the problems typically associated with national differences in accounting, statistical definitions, and other sources of methodological concern. ${ }^{13}$

In assembling our sample, we required banking systems to comply with the following criteria: (i) to be euro area banking system; and (ii) the availability of data in the OECD's bank statistics for the sampling period. Besides the PBS, the sample includes the banking systems of Austria, Belgium, Finland, France, Germany, Greece, Ireland, Italy, Luxembourg, the Netherlands and Spain.

The sample period starts in 1993 because this was the first year in which the 1988 Basel Accord on international bank capital standards was in force. Additionally, in 1992 the EEC Directive No. 86/635/CEE on accounting consolidation principles and rules for financial institutions, was transposed to the Portuguese legal system. The sample period ends in 2009 because this is the last year for which data was available in the OECD's bank profitability database. ${ }^{14}$

During the 1993-2009 period, two important events may have impacted differently the sample's banking systems. Therefore, we split our analysis into three sub-sample periods: (i) 1993-1998 to account for the period since the enforcement

\footnotetext{
${ }_{11}$ Differences in national accounting principles and practices, consolidation rules, reporting methods, tax codes, regulatory regimes, and statistical definitions make the comparability of banking statistics provided by national central banks difficult. Therefore, the examination of banking systems' datasets may become problematic, and their results should be interpreted cautiously (see OECD, 2011, pp. 3, 7).

12 The dataset for this empirical examination was drawn from: $\operatorname{OECD}(2012,2011,2008,2005,2003$, 2001). These publications provide «statistics on financial statements of banks in OECD countries. National Statistics are re-classified and presented according to a standard framework». See also the 2011 methodological notes prepared by the OECD to improve the comparability and «facilitate the comprehension and the interpretation of the data».

13 The dataset used in this study refers to entire banking systems except for Greece and Portugal for which only commercial banks are included in the sample.

${ }_{14}$ See Appendix III for sample scope, data availability, and missing data.
} 
of the 1988 Basel Accord till euro adoption; (ii) 1998-2007 and 1998-2009 to account for the potential effects of euro adoption and the 2008 global financial crisis.

For Portugal, the OECD's Bank Profitability statistics refers «to financial statements of all (universal) banks with their head-offices in national territory, and to some resident bank-like institutions. Subsidiaries of foreign banks are included. Excluded from these statistics are savings banks, mutual agricultural credit banks, branches of foreign banks and money market funds. Excluded are also data on nonmonetary financial institutions: other financial intermediaries, financial auxiliaries, insurance companies and pension funds» (OECD, 2011, p. 462).

\section{Results}

For this examination, we estimated the performance measures over two segments of the sampling subperiod: one from 1993 to 1998, the last year before euro adoption, and the other from 1999 to 2009. To probe for the alleged effects of the 2008 global financial crisis, we also considered the 1999-2007 subperiod.

\section{Profitability}

Following the mainstream literature on accounting-based banking profitability measurement, we used the 'Return on Assets' (ROA) and the 'Return on Equity' (ROE), as estimators of banking systems' profitability (e.g., Petria et al., 2015).

Based on those indicators, we appraised the performance of the banking system, classifying banking systems as outperformers or underperformers, whenever the performance indicator was higher (lower) than the control sample's mean (median).

ROA is an accounting measure of the overall banking asset base economic profitability, which was estimated as the 'Net Income' divided by 'Net Total Assets'. ROE was estimated as the quotient between 'Net Income' and 'Equity', gauging the accounting profitability of the equity capital base.

The decomposition of those accounting measures of profitability is a technique that is recurrently used by academics and practitioners to improve understanding of the profitability generating process. We performed the standard Du Pont decomposition technique on this profitability analysis. ${ }^{15}$ Table 1 summarizes its variable specifications:

Table 1 - Du Pont profitability decomposition

\begin{tabular}{ll}
\hline Variable & Specification \\
\hline Profit margin & Net income / Operating income \\
\hline Asset utilization & Operating income / Total assets \\
\hline Leverage multiplier & Total assets / Equity capital \\
\hline Return on assets (ROA) & Profit margin x Asset utilization \\
\hline Return on equity (ROE) & Return on assets x Leverage multiplier \\
\hline
\end{tabular}

ROA was decomposed as the product of the 'profit margin' by the 'asset utilization'. Table 2 documents that, on average, the PBS outperformed the control sample's banking systems in terms of economic profitability, measured by the ROA,

15 The DuPont's ROE decomposition method was named after the DuPont Corporation started using the procedure in the 1920 s. 
in all segments of the sampling period, either in terms of means (medians). ${ }^{16}$

\begin{tabular}{|c|c|c|c|c|}
\hline \multirow{2}{*}{ Portugal (means) } & $1993 / 2009$ & $1993 / 1998$ & 1999/2007 & $1999 / 2009$ \\
\hline & $0.40 \%$ & $0.49 \%$ & $0.48 \%$ & $0.36 \%$ \\
\hline Control sample & $6.81 \%$ & $4.98 \%$ & $7.95 \%$ & $8.27 \%$ \\
\hline \multirow{3}{*}{$\begin{array}{l}\quad \text { (medians) } \\
\text { Portugal } \\
\text { Control sample }\end{array}$} & $1993 / 2009$ & $1993 / 1998$ & $1999 / 2007$ & $1999 / 2009$ \\
\hline & $0.46 \%$ & $0.49 \%$ & $0.45 \%$ & $0.46 \%$ \\
\hline & $0.00 \%$ & $0.00 \%$ & $0.00 \%$ & $0.00 \%$ \\
\hline
\end{tabular}

Source: OECD Banking Statistics

On average, the profitability of the PBS (hereafter, PBS) over the 1993/2009 period, outperformed the ROA of the other banking systems included in the control sample by 0.13 percent (median, 0.18 percent). The outperformance is more pronounced during the 1993/1998 sample subperiod. It is also worth noting that the highest difference in ROA's mean (median) was recorded during the 1993/1998 period, and the lowest during the 1999/2007 period.

The Du Pont decomposition of ROA (see Tables 3a and b), documents that over the sample period of 1993-2009 the PBS, on average, exhibited superior performance, in all segments of the sampling period, in terms of both profit margin (+o.84 percent) and asset utilization (+0.84 percent).

Table 3a - Profit margin

\begin{tabular}{l|c|c|c|c|}
\multirow{4}{*}{ (means) } & $1993 / 2009$ & $1993 / 1998$ & $1999 / 2007$ & $1999 / 2009$ \\
\cline { 2 - 5 } Portugal & $6.09 \%$ & $6.61 \%$ & $7.86 \%$ & $5.90 \%$ \\
\cline { 2 - 5 } Control sample & $5.44 \%$ & $7.46 \%$ & $4.70 \%$ & $5.00 \%$ \\
\cline { 2 - 5 } & $1993 / 2009$ & $1993 / 1998$ & $1999 / 2007$ & $1999 / 2009$ \\
\cline { 2 - 5 } (medians) & $19.78 \%$ & $6.58 \%$ & $7.49 \%$ & $7.73 \%$ \\
\cline { 2 - 5 } Portugal & $6.7 \% \%$ & $4.33 \%$ & $4.56 \%$ \\
\cline { 2 - 6 } Control sample & $5.22 \%$ & $7.50 \%$ &
\end{tabular}

Source: OECD Banking Statistics

During the 1993-1998 period, before the enactment of the euro area, the profit margin decreased across all sample banking systems (see Table 3a). This was possibly due to the conjoint effects of the relative 'turbulence' experienced on the Exchange Rate Mechanism (ERM) of the European Monetary System (EMS) during the early 1990s, and the more competitive playing field associated with the European Community (EC) single market in financial services, completed in 1992.

Table 3b - Asset utilization

\begin{tabular}{|c|c|c|c|c|}
\hline (means) & $1993 / 2009$ & $1993 / 1998$ & $1999 / 2007$ & $1999 / 2009$ \\
\hline \multirow{2}{*}{$\begin{array}{l}\text { Portugal } \\
\text { Control sample }\end{array}$} & $7.23 \%$ & $8.76 \%$ & $6.39 \%$ & $6.31 \%$ \\
\hline & $6.49 \%$ & $8.16 \%$ & $5.61 \%$ & $5.77 \%$ \\
\hline \multirow{3}{*}{$\begin{array}{l}\quad \text { (medians) } \\
\text { Portugal } \\
\text { Sample }\end{array}$} & $1993 / 2009$ & $1993 / 1998$ & $1999 / 2007$ & $1999 / 2009$ \\
\hline & $6.92 \%$ & $8.89 \%$ & $6.03 \%$ & $6.03 \%$ \\
\hline & $5.70 \%$ & $7.50 \%$ & $5.29 \%$ & $5.29 \%$ \\
\hline
\end{tabular}

Source: OECD Banking Statistics

${ }^{16}$ For the purposes of this profitability analysis, we classify a banking system as 'outperformer' whenever its performance indicator is above the control sample's mean (median). Otherwise, we classify it as 'underperformer'. 
Table 3b shows that over the 1993-2009 sampling period, on average, the PBS outperformed the control sample's asset utilization ratios (operating income to total assets), which exhibit a relatively stable pattern for both the PBS and the other sample banking systems. During all the segments of the sampling period, PBS dominated the other banking systems in terms of both means or medians.

ROE is a popular accounting-based metric of the financial profitability of shareholders' equity. ${ }^{17}$ To extend the analysis, we decomposed the ROE in terms of the product of ROA and the equity multiplier ratio, which is the inverse of the capital ratio:

$$
R O E=R O A \frac{\text { Total Assets }}{\text { Equity }}
$$

Table 4 documents that, on average, the ROE of the PBS lagged other sample banking systems in every sample subperiod, in all segments of the sampling period, either in terms of means or medians $(-4.33$ and -3.30 percentage points, respectively). This underperformance was more pronounced during the 1993/1998 sample subperiod. It is also worth mentioning that the highest difference in ROA's mean (median) was recorded during the 1993/1998 subperiod, and the lowest during the 1999/2007 subperiod.

Table $4-$ ROE

\begin{tabular}{l|c|c|c|c|}
\multirow{4}{*}{ (means) } & $1993 / 2009$ & $1993 / 1998$ & $1999 / 2007$ & $1999 / 2009$ \\
\cline { 2 - 5 } $\begin{array}{l}\text { Portugal } \\
\text { Control sample }\end{array}$ & $5.86 \%$ & $6.66 \%$ & $5.99 \%$ & $5.06 \%$ \\
\cline { 2 - 5 } (medians) & $10.20 \%$ & $9.53 \%$ & $11.85 \%$ & $9.63 \%$ \\
\cline { 2 - 5 } & $1993 / 2009$ & $1993 / 1998$ & $1999 / 2007$ & $1999 / 2009$ \\
\cline { 2 - 5 } $\begin{array}{c}\text { Portugal } \\
\text { Control sample }\end{array}$ & $6.13 \%$ & $6.26 \%$ & $5.37 \%$ & $5.50 \%$ \\
\cline { 2 - 5 } & $9.43 \%$ & $7.33 \%$ & $8.99 \%$ & $9.12 \%$ \\
\hline
\end{tabular}

Source: OECD Banking Statistics

The ROE decomposition as the product of the 'ROA' (see Table 2 supra) and the 'Equity Multiplier' (see Table 5 infra), indicates that, despite outperforming other banking systems in terms of ROA, the PBS underperforms in terms of ROE because it is significantly less leveraged than the banking systems included in the control sample.

Table 5 - Equity Multiplier

\begin{tabular}{l|c|c|c|c|}
\multirow{4}{*}{$\begin{array}{l}\text { (means) } \\
\text { Portugal }\end{array}$} & $1993 / 2009$ & $1993 / 1998$ & $1999 / 2007$ & $1999 / 2009$ \\
\cline { 2 - 5 } Control sample & 9.75 & 10.93 & 9.11 & 8.80 \\
\cline { 2 - 5 } & 21.50 & 23.10 & 20.55 & 20.57 \\
\cline { 2 - 6 } (medians) & $1993 / 2009$ & $1993 / 1998$ & $1999 / 2007$ & $1999 / 2009$ \\
\cline { 2 - 5 } & 9.57 & 11.01 & 9.07 & 8.85 \\
\cline { 2 - 5 } Portugal & 20.36 & 21.32 & 20.06 & 19.73 \\
Sample & & & &
\end{tabular}

Source: OECD Banking Statistics

Any accounting-based performance analysis, despite its specific scope and methodological implementation, should be conducted in a risk-return framework.

\footnotetext{
${ }_{17}$ As shareholders' equity is the difference between the total net assets and the total liabilities, ROE can be viewed as a measure of the return on net assets.
} 
The literature documents several accounting-based specifications of business risk. For example, Psillaki and Daskalakis (2009) measure risk as the squared deviation of each year's earnings before taxes from the period average; de Jong et al. (2008) estimate business risk as the standard deviation of operating income over the book value of total assets; Kale et al. (1991) proxy the business risk of a firm's assets, by the coefficient of variation of a firm's operating cash flow; and Titman and Wessels (1988) measure business risk as the standard deviation of the percentage change in operating income.

In a banking risk-return framework, profitability accounting-based measures should be contrasted with an adequate measure of risk. To that end, we estimated the accounting-based indicator of risk, risk index $(R I)$, developed in Hannan and Hanweck's (1988):

$$
R I=\frac{E(R O A)+\frac{E}{A}}{\sigma_{R O A}},
$$

where $E(R O A)$ denotes the expected value of the return on assets ratio, $E$ / $A$ is the capital ratio (equity-to-net total assets), and $\sigma_{R O A}$ stands for the standard deviation of the return on assets.

The RI measures, in terms of units of ROA's standard deviation, how much accounting earnings can fall before becoming negative. Therefore, a reduced $R I$ score may reflect, either profitability or capitalization performance problems and, concomitantly, a relatively riskier banking system.

Table 6 | Risk Index

\begin{tabular}{|c|c|c|c|c|c|c|c|c|c|c|c|c|c|c|c|c|}
\hline & \multicolumn{4}{|c|}{$1993 / 2009$} & \multicolumn{4}{|c|}{$1993 / 1998$} & \multicolumn{4}{|c|}{ 1999-2007 } & \multicolumn{4}{|c|}{ 1999/2009 } \\
\hline & $R I$ & $\begin{array}{c}E \\
(R O A)\end{array}$ & $E / A$ & $\sigma_{R O A}$ & $R I$ & $\begin{array}{c}E \\
(R O A)\end{array}$ & $E / A$ & $\sigma_{R O A}$ & $R I$ & $\begin{array}{c}E \\
(R O A)\end{array}$ & $E / A$ & $\sigma_{R O A}$ & $R I$ & $\begin{array}{c}E \\
E \\
(R O A)\end{array}$ & $E / A$ & $\sigma_{R O A}$ \\
\hline Portugal & 71.0 & 0.0058 & 0.1041 & 0.0015 & 128.8 & 0.0059 & \begin{tabular}{|l|l|}
0.0920 \\
\end{tabular} & 0.0008 & 61.9 & 0.0058 & 0.1107 & 0.0019 & 118.2 & 0.0065 & 0.1140 & 0.0010 \\
\hline Control sample & 32.2 & 0.0043 & 0.05255 & 0.0018 & 16.2 & 0.0035 & 0.0469 & 0.0031 & 23.1 & 0.0048 & 0.0545 & 0.0026 & 23.4 & 0.0059 & 0.0548 & 0.0026 \\
\hline
\end{tabular}

Source: OECD Banking Statistics

where $R I$ denotes risk index; $E(R O A)$ expected value of ROA; $E / A$ capital ratio; and $\sigma_{R O A}$ ROA standard deviation.

According to the RI measure, over the 1993-2009 period, the PBS was, on average, less risky than the control sample's banking systems, because of its higher ROA performance and lower variability, and lower financial leverage. ${ }^{18}$ During the pre-Economic and Monetary Union period (1993-1998), the $R I$ score of the PBS escalated more than 80 percent due to a more than 50 percent decrease in ROA volatility. However, over the 1999-2007 subperiod, the riskiness of the PBS, increased by more than 50 percent because of a 20 percent drop in leverage, and a 147 percent increase in ROA volatility, compared to the 1993-1998 subperiod. Finally, the evidence for the 1999-2009 subperiod suggests that the 2008 financial crisis may have induced a 91 percent reduction in the riskiness of the PBS, due to a 13 percent rise in the average ROA and a 46 percent drop in its volatility, when compared to the 1999-2007 subperiod.

${ }_{18}$ Since the equity multiplier is the inverse of the capital ratio, the observed variation represents an improvement in the level of capitalization and, consequently, all else constant, a potential reduction in the risk of insolvency. 
Also noteworthy is that during all sample subperiods, the $R I$ for the control sample banking systems remained less volatile than the RI of the PBS, due to relatively more stabilized ROA variability.

Following, e.g., Kale et al. (1991), we used the relative variability of ROA and ROE, measured by their coefficients of variation, as surrogates for the exposure to the portfolio of risks embedded in the operating and net income of a banking system.

Coefficient of variation estimates suggests that both the ROA and ROE of the PBS were, on average, significantly less volatile than for the control sample banking systems.

Table 7 | ROA's and ROE's coefficient of variation

\begin{tabular}{|l|l|l|}
\cline { 2 - 3 } \multicolumn{1}{c|}{} & Portugal & Sample \\
\hline ROA & 0.2663 & 0.4243 \\
\hline ROE & 0.2611 & 0.4797 \\
\hline
\end{tabular}

Source: OECD Banking Statistics

From that standpoint, the PBS, during the 1993-2009 sampling period, was less risky than the other banking systems included in the sample. This result is consistent with Hannan and Hanweck's RI, which also indicates that, on average, the riskiness of the PBS was lower than in other sampled banking systems.

\section{Operating Efficiency}

Table 8 presents the accounting-based measures estimated to assess cost and income operating efficiency:

Table 8 | Operating Efficiency

\begin{tabular}{|c|c|c|c|c|c|c|c|c|c|c|c|c|}
\hline & \multicolumn{4}{|c|}{ 1993-2009 } & \multicolumn{4}{|c|}{$1993-1998$} & \multicolumn{4}{|c|}{ 1999-2009 } \\
\hline & \multicolumn{2}{|c|}{ Portugal } & \multicolumn{2}{|c|}{ Sample } & \multicolumn{2}{|c|}{ Portugal } & \multicolumn{2}{|c|}{ Sample } & \multicolumn{2}{|c|}{ Portugal } & \multicolumn{2}{|c|}{ Sample } \\
\hline & Mean & Median & Mean & Median & Mean & Median & Mean & Median & Mean & Median & Mean & Median \\
\hline Operating Income / Total Assets & 0.0723 & 0.0692 & 0.0637 & 0.0570 & 0.0876 & 0.0889 & 0.0793 & 0.0740 & 0.0639 & 0.0603 & $0.055^{2}$ & 0.0529 \\
\hline Interest Income / Total Assets & 0.0627 & 0.0605 & 0.0546 & 0.0509 & 0.0789 & 0.0807 & 0.0694 & 0.0684 & 0.0539 & 0.0521 & 0.0466 & 0.0431 \\
\hline Cost to income ratio & 0.5809 & 0.5709 & 0.6043 & 0.6080 & 0.6044 & 0.6091 & 0.6445 & 0.6665 & 0.5681 & 0.5657 & 0.5823 & 0.5988 \\
\hline Operating Expenses / Operating Income & 0.2331 & 0.2338 & 0.2332 & 0.2433 & 0.2225 & 0.2179 & 0.2286 & 0.2257 & 0.2408 & 0.2464 & 0.2357 & 0.2589 \\
\hline Operating Expenses / Total Assets & 0.2228 & 0.2338 & 0.2228 & 0.2433 & 0.1898 & 0.2179 & 0.1992 & 0.2257 & 0.2408 & 0.2464 & 0.2357 & 0.2589 \\
\hline Interest Expenses / Total Liabilities & 0.0488 & 0.0477 & 0.0423 & 0.0391 & 0.0617 & 0.0647 & $0.055^{2}$ & 0.0529 & 0.0417 & 0.0395 & 0.0353 & 0.0305 \\
\hline Net interest margin & 0.0189 & 0.0179 & 0.0144 & 0.0138 & 0.0228 & 0.0216 & 0.0168 & 0.0174 & 0.0168 & 0.0167 & 0.0131 & 0.0131 \\
\hline Staff Costs / Operating Income & 0.1172 & 0.1199 & 0.1182 & 0.1354 & 0.1196 & 0.1198 & 0.1187 & 0.1347 & 0.1159 & 0.1199 & 0.1180 & 0.1360 \\
\hline Staff Costs / Operating Expenses & 0.5048 & 0.5010 & 0.5037 & 0.5497 & 0.5471 & 0.5523 & 0.5347 & 0.5543 & 0.4818 & 0.4798 & 0.4867 & 0.5451 \\
\hline
\end{tabular}

Source: OECD Banking Statistics

Overall, during the 1993-2009 sampling period, the PBS, on average, outperformed the other banking systems in terms of operating and interest income efficiency. We also found that the means (medians) of both the operating and the interest income to total assets drop after the euro was launched on 1 January 1999. This may be possibly due to the convergence of the interest rates prior to the EMU (e.g., Frömmel and Kruse, 2015), and to the more intense competition as the integration of the EU banking and financial markets progressed. However, results document that the control sample's banking systems were more cost to income efficient.

In terms of the efficiency of the operating and the interest expenses, we did not find statistically significant differences between the performance of the PBS and the control sample banking systems (see Table 9).

Results of two-side $t$-tests on the equality of means on two (unpaired data) samples, 
under the null of equality of means, reveal that only the means of the net interest margin are statistically different, at the 1 percent level. Results are robust to the use of the median statistic.

Source: OECD Banking Statistics

Table 9 | Operating Efficiency - tests on the equality of means

**** Denotes statistical significance at the 1 percent level.

\begin{tabular}{ll}
\cline { 2 - 2 } & $\begin{array}{c}\text { Two-sided } \\
\text { t-test }\end{array}$ \\
\hline Operating Income / Total Assets & 1.6507 \\
Interest Income / Total Assets & 1.5878 \\
Cost to income ratio & -1.6373 \\
Operating Expenses / Operating Income & -0.0150 \\
Operating Expenses / Total Assets & -0.0029 \\
Interest Expenses / Total Liabilities & 1.4458 \\
Net interest margin & $4.2863^{* * *}$ \\
Staff Costs / Operating Income & -0.2063 \\
Staff Costs / Operating Expenses & 0.0902 \\
\hline
\end{tabular}

Finally, we failed to find significant differences in the means of the staff costs to operating income and expenses ratios.

\section{Liquidity and Credit Risk}

The financial intermediation function exposes banking organizations to idiosyncratic risks. Among them are liquidity and credit risks.

Typically, economic agents have a preference for liquidity. In this framework, «the probability of not being liquid would suggest that there is liquidity risk» (Nikolaou (2009, p. 15). From this standpoint, banking liquidity risk can be rationalized as the probability of a bank finding itself unable to meet the timely repayment of short-term liabilities or refinance the assets it holds on its balance sheet. In other words, liquidity risk is closely associated with the diminished, actual or potential, ability of a bank to autonomously ensure the (re)financing of its assets and in meeting the financial obligations of its liabilities, as they are due.

We assumed as surrogates for liquidity risk, the following accounting-based measures: Liquidity risk I, specified as: [CCash and balance with Central bank + Interbank deposits) / Total Assets]; and Liquidity risk II, defined as: [(Cash and balance with Central bank + Interbank deposits) / Short-term liabilities].

According to the definition by the Bank for International Settlements (BIS), «credit risk is most simply defined as the potential that a bank borrower or counterparty will fail to meet its obligations in accordance with agreed terms» (see Basel Committee on Banking Supervision, 2000). Thus, credit risk refers to the likelihood that a borrower will default on his/her obligations to pay principal and interests in a timely manner. To assess the exposure to credit risk, we estimated the ratio Provisions on Loans-to-Loans. 


\begin{tabular}{lcccc}
\cline { 2 - 5 } & \multicolumn{2}{c}{ Portugal } & \multicolumn{2}{c}{ Sample } \\
\cline { 2 - 5 } & Mean & Median & Mean & Median \\
\hline Liquidity risk I & 0.2580 & 0.2576 & 0.2326 & 0.2161 \\
Liquidity risk II & 0.3621 & 0.3397 & 0.2742 & 0.2482 \\
Credit risk & 0.0112 & 0.0101 & 0.0060 & 0.0056 \\
\hline
\end{tabular}

Source: OECD Banking Statistics

Results demonstrate that, on average, the PBS during the 1993-2009 period was less exposed to the liquidity risk, either in the shorter or longer term, than its sample's peers.

In terms of credit risk, we found that the PBS, on average, has underperformed the other banking systems, exhibiting a relatively higher level of non-performing loans to credit portfolio, than its sample counterparts.

\section{Income Taxation}

Corporate income tax liability is a relevant component of banks' performance. Although banks are not prototypical taxpayers, both theoretical and empirical research suggests that banks design tax policies and manage their tax liability so as to adjust «their economic balance sheets as their tax-paying status» changes. Other symptoms appear to reinforce the notion that banks, either in aggregate or at the individual level, seem to accommodate to the modifications in the tax regime (Scholes et al., 1990).

According to Albertazzi and Gambacorta (2010), concerning the relationship between banking profitability and taxation, using a dataset for the banking systems of a sample of countries (including Portugal), drawn from the OECD banking profitability database, over the 1981-2003 sampling period, they found that (i) banks' income taxes are strongly related to banking revenues and, (ii) because of their financial intermediation functions, banks may be able to manage their income tax liability, and therefore «differences in the level of taxation cannot explain the dispersion observed in banks' net profitability across (...) countries» (Ib. p. 2801).

To assess the income-tax status of the banking systems included in our sample, we estimated the implicit tax rate as the quotient between income tax and earnings before taxes. ${ }^{19}$

Table 10 - Implicit Income Tax Rate

\begin{tabular}{|c|c|}
\hline & Median (\%) \\
\hline Portugal & 0.1755 \\
\hline Sample & 0.1993 \\
\hline
\end{tabular}

From 1993 through to 2009, the median implicit tax rate estimated for the PBS is $\mathbf{1 7 . 5 5}$ percent (mean $\mathbf{1 7 . 4 0}$ percent). This result documents that, on average, the banks integrated into the PBS were 'undertaxed' relative to their sample peers, based on the sample's median implicit tax rate (19.93 percent). These findings are in line with prior research (see, e.g., Coutinho dos Santos, 2003), which, using data from the Portuguese Banks' Association (APB), estimated an average implicit tax rate of

19 Due to potential outliers involving data for Denmark (1994), France (1994), Germany (2003), and Greece (2009) for which we were unable to find any satisfactory explanation in the OECD Banking Statistics: Methodological Country Notes, we used the median as a measure of central tendency. 
18.48 percent, and 20.46 percent net total assets weighted average, over the 19891998 period.

\section{Capitalization}

It is well-established in the literature that bank capital and profitability are intertwined, and consequently simultaneously determined by both exogenous and endogenous factors (e.g., Coutinho dos Santos, 2021; Vasiliou and Karkazis, 2002; Kwan and Eisenbeis, 1997)..$^{\circ}$ For example, García-Herrero et al. (2009) document a positive relationship between banking capitalization and profitability for a sample of Chinese banks during the 1997-2004 sample period. According to Goddard et al. (2004), «banks that maintain a high capital-assets ratio tend to grow slowly, and growth is linked to macroeconomic conditions. Banks that maintain high capitalassets or liquidity ratios tend to record relatively low profitability».

Further, prior research on banking capitalization raised some relevant and still unanswered questions. For example, «why do capital ratios of these roughly similar banking organizations vary so much across different developed countries? » (Brewer III et al. (2008, p. 178); and (ii) Why, since the enforcement of the 1988 Basel Accord, do banks hold capital ratios in excess of the regulatory minima? (Harding et al. 2013; Gropp and Heider 2010; Berger et al. 2008; Brewer III et al. 2008; Flannery and Rangan 2008).

The amount of capital a bank carries on its balance sheet, and the functions it plays, have been thoroughly debated in the literature. In summary, bank capital economic functions include serving as: (i) a guarantee of financial independence, and to some extent, to allow easier and less costly access to debt financing; (ii) cofunding of a bank's growth, and therefore its competitive strategy implementation; (iii) a reassurance to creditors of the value of their claims; (iv) a buffer for bank potential losses in particularly adverse states of nature, as may be the case regarding severe economic downturns (e.g., Saunders and Cornett, 2007, p. 586; Berger et al., 1995); and $(v)$ a shield for potential losses in charter and franchise values of banks holding valuable reputational capital investments (e.g., Demsetz et al., 1996). ${ }^{21}$

Bank capitalization condition can be assessed under different approaches. Namely, accounting-based, market-based, and regulatory-based. The accountingbased capital ratio - equity capital to total net assets - measures a bank's capacity to absorb unforeseen losses. In abstract, an excessively high capital ratio may indicate that a bank could be overcapitalized in comparison to an appropriate benchmark. As the cost of equity capital is higher than the cost of debt, that bank would have a relatively higher cost of capital.

Under the market-based approach, banks' capitalization is closely related to the 'tradeoff' between the level of financial leverage taken on, and market valuation, and therefore, the amount of equity capital a bank carries on its balance sheet is not a

\footnotetext{
${ }^{20}$ See also Goddard et al. (2004), Demirgüç-Kunt and Huizinga (1999) and Berger (1995) for additional evidence on the positive relation between bank capitalization and profitability, for the U.S., the European and industrial and emerging countries' banking systems.

${ }^{21}$ The economic value of a bank's equity capital is the difference between its assets and liabilities, both marked-to-market.
} 
matter of indifference (e.g., Greenbaum et al., 2016; Berger et al., 1995). Therefore, we should expect that a bank with a low capital ratio would, ceteris paribus, exhibit a high financial risk, and bear a relatively high cost of capital, and consequently a lower market value. There is empirical evidence documenting that banks seem to adjust their marked-to-market capitalization levels to target leverage ratios (e.g., Flannery and Rangan, 2008; Berger et al, 2008).

The regulatory approach to banking capitalization is determined by the mandatory compliance with regulatory capital requirement determinations (e.g., Besanko and Kanatas, 1996; Cornett and Tehranian, 1994).

Under levered equityholder limited liability framework, banks' residual claimants have a call option on their underlying assets. As the value of that call is positively related to the increases in the volatility of the underlying asset, bank owners have an incentive for moral hazard opportunistic behavior, taking in excessive and inefficient risk, either in the form of claim dilution or asset substitution (see, e.g., John et al., 1991; Kim and Santomero, 1988).

Governments worldwide implemented banking deposit insurance to protect depositors' claims against banks' excessive risk-taking. ${ }^{22}$ However, inefficiently priced deposit insurance premia, meaning that they are insensitive to banks' asset riskiness, creates an incentive for banks taking potentially inefficient risk, aiming at maximizing the value of the put-option subsidy on the inefficiently priced deposit insurance. ${ }^{23}$

As insured depositors cannot completely monitor bank owners/managers' actions, this aspect can increase the value of their call option by increasing the riskiness of the bank's underlying assets. However, a bank's uninsured depositors and other creditors do have an incentive to monitor the bank risk-taking actions demanding a higher return on their claims. Thus, ceteris paribus, the higher the incentives for equityholders to transfer wealth for their own benefit, at depositors and other debtholders' expense, the lower the bank's financial leverage is, and the higher its capital ratio is. Consequently, in banking systems where public deposit insurance is priced insensitively to asset risk, bank owners are provided with a distortionary incentive to increase bank's riskiness. ${ }^{24}$ In this case, the banking firm is encouraged to leverage-up because of the advantageous cost of deposit funding due to the subsidy granted by public deposit insurers at taxpayers' expense. Shareholders, instead of using their own financing or risk sensitive debt-financing to fund bank growth, are very likely to use deposit financing, further enhancing the probability of potentially disruptive and costly insolvency.

Under the jurisdiction of BIS, a group of countries, formally adopted the Basel Accord in 1988, establishing the first formal banking capital adequacy standard. The

${ }^{22}$ As argued in John et al. (1991), even with risk-adjusted deposit insurance premia, incentives for riskshifting will still be present. Therefore, the propensity for excessive risk-taking cannot be exclusively attributed to risk-insensitive deposit insurance pricing.

23 Merton (1977) shows that the government deposit guarantee can be viewed as a put option for banks. The insensitivity of the deposit insurance premium to bank's asset riskiness is related to assets' informational opacity, which prevents outsider investors from accurately assessing asset risk and pricing it at its actuarially fair value.

24 Milney and Whalley (2001) show that «incentives for risk taking depend upon this buffer of capital in excess of the regulatory minimum, not the total level», and «the regulatory capital requirement has no long run effect on bank risk-taking». 
regulatory risk-based bank capital adequacy requirements introduced an explicit relationship between bank capital and risk, establishing a mandatory minimum capital regulatory ratio, and making the regulatory capital base (Tier 1 and Tier 2) responsive to changes in banks' portfolio exposure to credit risk (see, e.g., Basel Committee on Banking Supervision, 1999; Wall and Peterson, 1996; Furlong and Keeley, 1989). ${ }^{25}$

Under the Basle 1988 Accord, the capital regulatory ratio was computed as:

$$
\text { Capital Regulatory ratio }=\frac{\text { Total } \text { regulatory capital }(=\text { Tier } 1+\text { Tier } 2)}{\text { Total risk weighted assets }}
$$

The observation of the capital structure of real-world banks suggests that capital ratios seem to revert, like non-banking firms, to some target ratios, which, on average, are above the ones of non-banking firms. This evidence is consistent with the view that the capital structure of banks matters (e.g., Crouhy and Galai 2018; DeAngelo and Stulz 2015; Gropp and Heider 2010; Berger et al. 2008; Brewer III et al. 2008; Flannery and Rangan 2008).

We use the accounting-based capital ratio as the yardstick to gauge a banking system's capitalization condition. During the examination of the banking capitalization condition, we classified a banking system as 'overleveraged' whenever its capital ratio was higher than the sample's banking system capital ratio mean (median), and as 'underleveraged', when the capital ratio was lower than the control sample's capital ratio mean (median).

\section{Figure 1 | Book Capital Ratios}

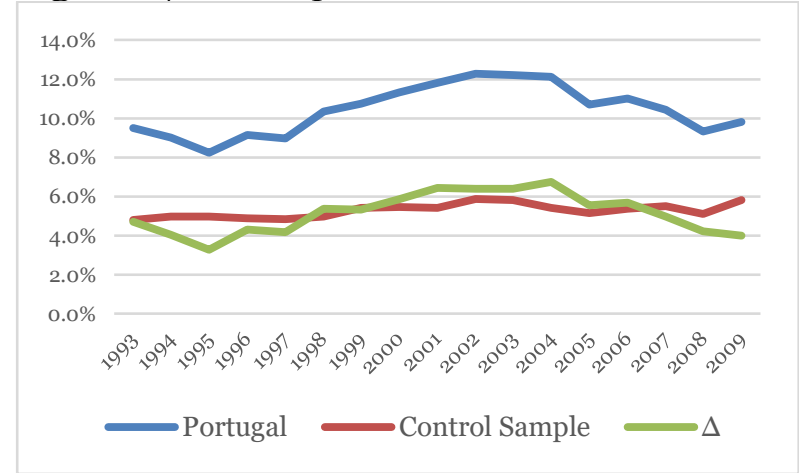

Source: OECD Banking Statistics

Figure 1 documents that the PBS experienced a sustained buildup of its capitalization level between 1997 and 2004, followed by a period of decline.

A buildup of banking capitalization should be expected to comply with the new capital standards, fully enforced by 1992. In addition, it may be also conjectured that

25 The Basle Capital Accord, formally adopted in July 1988, established a framework for banking capital measurement and the requirements of bank capital adequacy, which were expected to meet compliance by the end of 1992. See, e.g., Fraser and Monimer-Lee (1993). 
a capital pile up should be expected in preparation for the privatization program underway in the PBS during the 1989-1996 timeframe. ${ }^{26}$

During the 1993-2009 period, we found that the PBS, on average, exhibited a capital ratio 5.15 percent above the sample's mean, and 5.53 percent above the median. This finding suggests that, on average, the PBS was underleveraged, compared to the sample's banking system. This pattern prevails over the sampling subperiods (see Table 11).

Table 11 | Book value capital ratios

\begin{tabular}{|l|c|c|c|c|}
\cline { 2 - 5 } \multicolumn{1}{c|}{ means } & $1993 / 2009$ & $1993 / 1998$ & $1999 / 2007$ & $1999 / 2009$ \\
\hline Portugal & $10.41 \%$ & $9.20 \%$ & $11.07 \%$ & $11.40 \%$ \\
\hline Sample & $5.25 \%$ & $4.94 \%$ & $5.45 \%$ & $5.48 \%$ \\
\hline (over) / underleveraged & $5.15 \%$ & $4.26 \%$ & $5.62 \%$ & $5.93 \%$ \\
\hline & $1993 / 2009$ & $1993 / 1998$ & $1999 / 2009$ & $1999 / 2007$ \\
\hline & $10.45 \%$ & $9.08 \%$ & $11.02 \%$ & $11.30 \%$ \\
\hline Portugal & $4.91 \%$ & $4.69 \%$ & $4.98 \%$ & $5.07 \%$ \\
\hline Sample & $5.53 \%$ & $4.39 \%$ & $6.04 \%$ & $6.23 \%$ \\
\hline (over) / underleveraged & & &
\end{tabular}

Source: OECD Banking Statistics

The table below presents the capital regulatory ratios estimated for PBS and the control sample's banking systems, for all the sub-sampling periods. ${ }^{27}$

Table 12 | Regulatory capital ratios

\begin{tabular}{|l|c|c|c|c|}
\multicolumn{1}{c}{ means } & $1993 / 2009$ & $1993 / 1998$ & $1999 / 2007$ & $1999 / 2009$ \\
\hline Portugal & $11,81 \%$ & $11,79 \%$ & $11,82 \%$ & $11,78 \%$ \\
\hline Sample & $13,42 \%$ & $12,04 \%$ & $13,75 \%$ & $13,61 \%$ \\
\hline (over) / underleveraged & $-1,61 \%$ & $-0,25 \%$ & $-1,92 \%$ & $-1,82 \%$ \\
\hline & $1993 / 2009$ & $1993 / 1998$ & $1999 / 2009$ & $1999 / 2007$ \\
\hline medians & $11,81 \%$ & $11,79 \%$ & $11,82 \%$ & $11,76 \%$ \\
\hline Portugal & $13,63 \%$ & $13,21 \%$ & $14,00 \%$ & $13,72 \%$ \\
\hline Sample & $-1,82 \%$ & $-1,43 \%$ & $-2,18 \%$ & $-1,96 \%$ \\
\hline
\end{tabular}

Source: OECD Banking Statistics

We found, based on the regulatory capital ratio yardstick that, on average, the PBS overleveraged the banking systems included in the control sample, with the exception of 1993, 1994 and 1995. The overleverage gap narrowed during the 19931998 (pre-euro) sample subperiod and widened for the remainder of the sampling period. Results are robust to the use of the median statistic.

Figure 2 | Regulatory Capital Ratio

\footnotetext{
${ }^{26}$ Based on Wall and Peterson's (1987) hypothesis that the mandatory capital requirements enforced by U.S. bank regulators in 1981 influenced changes in large bank holding companies in the three subsequent years, we conjecture that regulatory capital ratios of both the PBS and control sample's banking systems may have risen until the 1988 Basel Accord capital adequacy standards were enforced in 1992.

27 As reported in Appendix III, there is data missing in the OECD Banking Statistics database needed to compute the 'Capital regulatory ratio' for Denmark, Finland, France, Germany, and Luxembourg.
} 


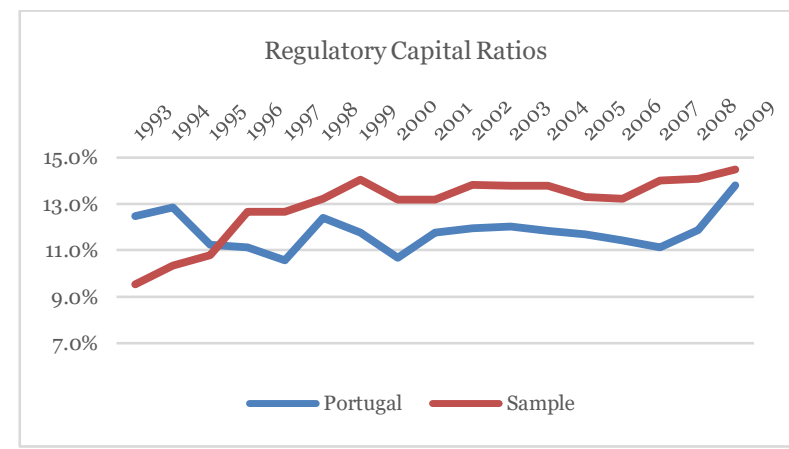

Source: OECD Banking Statistics

To summarize, using the 'Capital regulatory ratio' to measure the banking system's average capital adequacy, we found that during the sampling period, the capital regulatory ratio of the PBS was for most of the sampling period below the mean/median of the other sampled banking systems, and consequently, from this standpoint, it could be considered as being undercapitalized.

The cross-sectional observation of the regulatory capital ratio for the control sample (see Table 13), documents that the banking systems of Greece, Netherlands, and Spain, on average, exhibited a below the sample mean (median) regulatory capital ratio during the 1999-2009 sampling sub-period. These results suggest that those four banking systems could be considered as undercapitalized, compared to mean (median) regulatory capitalization of the control sample.

Table 13 | Control sample's regulatory capital ratios

\begin{tabular}{|l|c|c}
\cline { 2 - 3 } \multicolumn{1}{c|}{} & Mean & Median \\
\hline Austria & $15.49 \%$ & $14.99 \%$ \\
\hline Belgium & $14.65 \%$ & $13.71 \%$ \\
\hline Greece & $12.91 \%$ & $12.72 \%$ \\
\hline Ireland & $13.93 \%$ & $13.89 \%$ \\
\hline Italy & $13.63 \%$ & $13.59 \%$ \\
\hline Netherlands & $11.43 \%$ & $11.48 \%$ \\
\hline Spain & $11.91 \%$ & $12.09 \%$ \\
\hline Sample mean & $13.42 \%$ & $13.59 \%$ \\
\hline
\end{tabular}

Source: OECD Banking Statistics

It is worth noting that during the 2011-2014 period, the banking systems of Greece, Portugal, and Spain have been involved, in different forms and scales, with the multilateral financial assistance from the European Commission, the European Central Bank and the International Monetary Fund.

Under the international risk-based capital requirements framework, in the form of a regulatory capital ratio - such as the Basel Capital Accord - a value-maximizing bank has incentives to increase the numerator of the regulatory capital ratio by issuing new internal and/or external regulatory capital, following a rise in its riskweighted asset base, to comply with regulatory requirements.

Under this rationale, we should expect a positive correlation between annual changes in regulatory capital and the annual changes in the 'average implicit risk weight' in the regulatory capital ratio, which we estimated as: 


\section{Total regulatory capital \\ Total Assets $\times$ Capital regulatory ratio}

The implicit average risk weight is a regulatory-based measurement of banking system's off and on-balance sheet asset base.

To implement this analysis, we specified the variables included in Table 12:

Table 12 | Average implicit risk weight

\begin{tabular}{ll}
\hline Variables & Specification \\
\hline Average Implicit risk weight & $\begin{array}{l}\text { Total regulatory capital / (Total assets x Capital } \\
\text { regulatory ratio) }\end{array}$ \\
\hline Average implicit risk weight variation & $\left(\right.$ Implicit risk weight $t /$ Implicit risk weight $\left.t_{t-1}\right)-1$ \\
\hline Tier 1 variation & $\left(\right.$ Tier $1_{t} /$ Tier $\left.1_{t-1}\right)-1$ \\
\hline Source: OECD Banking Statistics &
\end{tabular}

Table 13 presents the average implicit risk weigh estimates:

Table 16 - Implicit risk weight

\begin{tabular}{|c|c|}
\cline { 2 - 2 } \multicolumn{1}{c|}{} & Mean \\
\hline Portugal & 0.5778 \\
\hline Austria & 0.3938 \\
\hline Belgium & 0.2605 \\
\hline Greece & 0.4698 \\
\hline Ireland & 0.4103 \\
\hline Italy & 0.5702 \\
\hline Netherlands & 0.4608 \\
\hline Spain & 0.4607 \\
\hline Sample & 0.4409 \\
\hline
\end{tabular}

Source: OECD Banking Statistics

The average implicit risk weight estimated for Portugal (0.5778) is 31 percent higher than the control sample's (0.4409), which indicates higher credit riskiness of the off and on-balance sheet assets of the PBS. ${ }^{28}$

Figure 2 exhibits a pattern of weak correlation between the changes in the average implicit risk weight, and the changes in regulatory capital of the PBS.

Figure 2 | Implicit Risk Weight vs Regulatory Capital Changes of the PBS

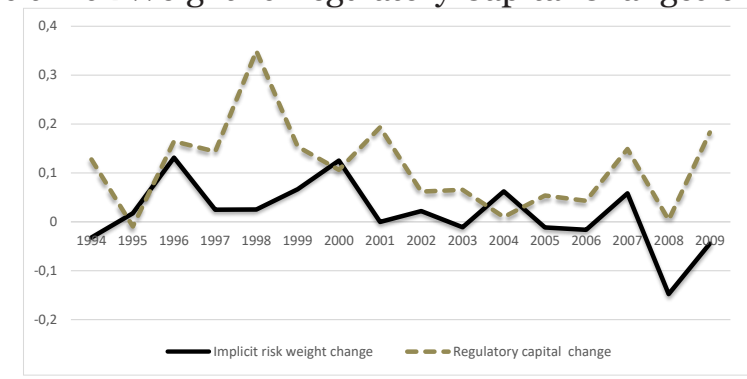

Source: OECD Banking Statistics

The linear association of the two variables, measured by Pearson's correlation, yield the weak correlation coefficients of $r=0.00194$ and $r=0.00054$, for both the

28 The Basel Capital Accord assigned o, 10, 20, 50 and 100 percent risk weights to different categories of on-balance sheet assets, and off-balance-sheet exposures. See International Convergence of Capital Measurement and Capital Standards (July 1988, updated to April 1998), available at: http://www.bis.org/publ/bcbsc111.pdf. 
contemporaneous and the one-year lagged correlation, respectively. At the 5 percent significance level, the null hypothesis of no correlation in the population $(r=0)$ could not be rejected, for both correlation coefficients.

This evidence is not consistent with the hypothesis that changes in the average implicit risk weight, a proxy of the riskiness of the asset base of the PBS implicit in its regulatory capital ratio, should be correlated with the average annual percentage change in regulatory capital. This apparently 'anomalous' finding, may be explained by the use of regulatory capital arbitrage techniques, such as «securitization and other financial innovations that have provided unprecedented opportunities for banks to reduce substantially their regulatory capital requirements with little or no corresponding reduction in their overall economic risks» (Jones, 2000, p. 35).

\section{Summary of Findings and Concluding Remarks}

The paper examines, through the lens of accounting-based measures, the performance of the PBS, in comparison to a sample of Eurosystem's banking systems, in terms of profitability, operating efficiency and capitalization. In our empirical analysis, we found vis-à-vis: (i) Profitability that PBS outperformed the other banking systems, in terms of ROA, but underperformed relative to ROE. On average, the ROA of the PBS over the 1999-2009 and 1999-2007 sample subperiods was consistent with the conjecture that the fall in the return on assets may be one of the effects of the 2008 crisis. This fall in profitability, both in terms of ROA and ROE, during the 2008 financial crisis, naturally weakened the potential of the PBS to grow its capital base internally; (ii) During the overall sampling period, the PBS, on average, outperformed the other banking systems in terms of operating and interest income, cost to income, and net interest margin efficiency. However, it did not perform differently from the other sample banking systems in terms of the efficiency of the operating and the interest expenses. In addition, the PBS was less exposed to the liquidity risk, and underperformed the other banking systems in terms of credit risk. Finally, on average, during the overall sampling period, the banks integrated in the PBS were undertaxed relative to their sample peers, based on the median implicit tax rate; and (iii) Book-value capital ratios document that the PBS over the 1993-2009 sampling period outperformed the control sample banking systems in terms of capitalization. However, our estimates of the regulatory capital ratio, indicate that the PBS, on average, was undercapitalized vis-à-vis the other banking systems. This apparent ambiguity in the capitalization condition of the PBS may result, at least partially, from the different ambit of the denominator - net total assets - of the two capitalization measures. The book-value capital ratio includes, exclusively, the onbalance assets. The denominator of the regulatory capital ratio - the sum of riskweighted assets - includes both the on and the off-balance sheet assets. Additionally, the ambit of this capitalization measure numerator is broader as it also includes some non-equity claims. 


\section{REFERENCES}

Albertazzi, U. \& L. Gambacorta. 2009. Bank Profitability and the Business Cycle. Journal of Financial Stability 5(4): 393-409.

Albertazzi, U. \& L. Gambacorta. 2010. Bank Profitability and Taxation. Journal of Banking and Finance 34(11): 2801-2810.

Alpalhão, R. \& P. Pinho. 1990. Análise Financeira das Instituições de Crédito Portuguesas, 1980-89: Rentabilidade e Risco. Sociedade Financeira Portuguesa, Lisbon, Portugal.

Altunbas, Y., E. Gardener, P. Molyneux \& B. Moore. 2001. Efficiency in European Banking. European Economic Review 45(10): 1931-1955.

Avery, R. 1997. Off-Site Surveillance Systems in the 1980s and Lessons for the Future. History of the Eighties: Symposium proceedings, FDIC.

Balla, E. \& M. Rose. 2019. Earnings, Risk-Taking, and Capital Accumulation in Small and Large Community Banks. Journal of Banking \& Finance 103: 36-50.

Barreto, I. \& C. Baden-Fuller. 2006. To Conform or To Perform? Mimetic Behaviour, Legitimacy-Based Groups and Performance Consequences. Journal of Management Studies 43(7): 1559-1581.

Barros, P. \& P. Pinho. 1995. Estudos Sobre o Sistema Bancário Português. Banco Mello, Lisboa, Portugal.

Barth, J. \& R. Brumbaugh. 1994. Moral-Hazard and Agency Problems: Understanding Depository Institution Failure Costs. In G. Kaufmann, Editor, Research in Financial Services, Vol. 6: 61-102. Greenwich: JAI Press.

Barth, J., G. Caprio Jr. \& R. Levine. 2001. Banking Systems around the Globe: Do Regulation and Ownership Affect Performance and Stability? In F. Mishkin, Editor. Prudential Supervision: What Works and What Doesn't, chapter 2: 31-96. University of Chicago Press, Chicago (IL), USA.

Basel Committee on Banking Supervision. 1999. Capital Requirements and Bank Behaviour: The Impact of the Basel Accord. Basel Committee on Banking Supervision Working Paper No. 1, Bank for International Settlements.

Basel Committee on Banking Supervision. 2000. Principles for the Management of Credit Risk. Bank of International Settlements, Basel, Switzerland.

Berger, A. 1995. The Pro• t-Structure Relationship in Banking-Tests of Market-power and EfficientStructure Hypotheses. Journal of Money, Credit and Banking 27(2): 404-431.

Berger, A. \& D. Humphrey. 1997. Efficiency of Financial Institutions: International Survey and Directions for Future Research. European Journal of Operational Research 98(2): 175-212.

Berger, A., R. DeYoung, M. Flannery, D. Lee \& Ö Öztekin. 2008. How do Large Banking Organizations Manage their Capital Ratios? Journal of Financial Services Research 34: 123-149.

Berger, A., R. Herring \& G. Szegö. 1995. The Role of Capital in Financial Institutions. Journal of Banking and Finance 19(3-4): 393-430.

Berger, A., W. Hunter \& S. Timme. 1993. The Efficiency of Financial Institutions: A Review and Preview of Research Past, Present and Future. Journal of Banking and Finance 17(2-3): 221-249.

Besanko, D., \& G. Kanatas. 1996. The Regulation of Bank Capital: Do Capital Standards Promote Bank Safety? Journal of Financial Intermediation 5(2): 160-183.

Bikker, J. \& J. Bos. 2008. Bank Performance. Routledge, New York (NY), USA.

Bitar, M., K. Pukthuanthong \& T. Walker. 2018. The Effect of Capital Ratios on the Risk, Efficiency and Profitability of Banks: Evidence from OECD countries. Journal of International Financial Markets, Institutions and Money 53(C): 227-262.

Borges, A. 1993. Portuguese Banking in the Single European Market. In J. Dermine, Editor, European Banking in the 1990s, $2^{\text {nd }}$ Ed, Chapter 9: 325-343. Blackwell Publishers, Oxford, UK.

Bossone, B. 2000. What Makes Banks Special? A Study of Banking, Finance, and Economic Development. Policy Research Working Paper No. 2408. World Bank, Washington, DC.

Bouzgarrou, H., S. Jouida \& W. Louhichi. 2018. Bank Profitability During and Before the Financial Crisis: Domestic Versus Foreign Banks. Research in International Business and Finance 44: 26-39.

Cabrita, M. \& N. Bontis. 2008. Intellectual Capital and Business Performance in the Portuguese Banking Industry. International Journal of Technology Management 43(1-3): 212-237.

Canhoto, A \& J. Dermine. 2003. A Note on Banking Efficiency in Portugal, New vs. Old Banks. Journal of Banking and Finance 27(11): 2087-2098.

Coccorese, P. \& C. Girardone. 2020. Bank Capital and Profitability: Evidence from a Global Sample. The European Journal of Finance; DOI: https://doi.org/10.1080/1351847X.2020.1832902.

Chortareas, G. E., C. Girardone \& A. Ventouri. 2012. Bank Supervision, Regulation, and Efficiency: Evidence from the European Union. Journal of Financial Stability 8(4): 292-302.

Coelli, T., D. Rao, C. O’Donnell \& G. Battese. 2005. An Introduction to Efficiency and Productivity Analysis, $2^{\text {nd }}$ Ed. Springer, New York (NY), USA.

Cornett, M., \& H. Tehranian, 1994. An Examination of Voluntary Versus Involuntary Securities Issuances by Commercial Banks: The Impact of Capital Regulations on Common Stock Returns. Journal of Financial Economics 35(1): 99-122.

Cornett, M., J. McNutt \& H. Tehranian. 2009. Corporate Governance and Earnings Management at Large U.S. Bank Holding Companies. Journal of Corporate Finance 15: 412-430.

Coutinho dos Santos, M. 2021. Does the Corporate Capital Structure Theory Apply to Banks? Evidence from the Field. Working paper available at: https://ssrn.com/abstract=3772205; DOI: 
http://dx.doi.org/10.2139/ssrn.3772205.

Coutinho dos Santos, M. 2016. Performance and Efficiency of the Portuguese Banking System. In A. Sérgio, Editor, Banking in Portugal, Chapter 6: 83-124. Palgrave Macmillan Studies in Banking and Financial Institutions, London, UK. DOI: 10.1057/9780230371422_6.

Crouhy, M. \& D. Galai. 2018. Are Banks Special? Quarterly Journal of Finance 8(4): 1840004 (19 pages). D'Mello, R. \& R. Farhat. 2008. A Comparative Analysis of Proxies for an Optimal Leverage Ratio. Review of Financial Economics 17: 213-227.

de Jong, A., R. Kabir \& T. T. Nguyen. 2008. Capital Structure Around the World: The Roles of Firm- and Country-specific Determinants. Journal of Banking \& Finance 32: 1954-1969.

Damar, H., C. Meha \& Y. Terajima. 2013. Leverage, Balance-Sheet Size and Wholesale Funding. Journal of Financial Intermediation 22, 639-662.

De Jonghe, O. \& Ö. Öztekin. 2015. Bank Capital Management: International Evidence. Journal of Financial Intermediation 24, 154-177.

DeAngelo, H. \& R. Stulz. 2015. Liquid-claim Production, Risk Management, and Bank Capital Structure: Why High Leverage Is Optimal for Banks. Journal of Financial Economics 116: 219-236

Degryse, H., M. Kim \& S. Ongena. 2009. The Industrial Organization Approach to Banking. In Microeconometrics of Banking: Methods Applications, and Results, Chapter 3: 26-56. Oxford University Press, New York (NY), USA.

Dermine, J. 2003. Banking in Europe: Past, Present, and Future. In V. Gaspar, P. Hartmann and O. Sleijpen, Editors; The Transformation of the European Financial System. European Central Bank, Frankfurt, Germany.

Demirgüç-Kunt, A., \& H. Huizinga. 1999. Determinants of Commercial Bank Interest Margins and Profitability: Some International Evidence. World Bank Policy Research Working Paper No. 1900.

Dewatripont, M. \& J. Tirole. 1993. The Prudential Regulation of Banks. The MIT Press, Cambridge (MA), USA.

DeYoung, Robert \& Iftekhar Hasan.1998. The Performance of de Novo Commercial Banks: A Profit Efficiency Approach. Journal of Banking and Finance 22(5): 565-587.

Dietrich, A. \& G. Wanzenried. 2011. Determinants of Bank Profitability before and During the Crisis: Evidence from Switzerland. Journal of International Financial Markets, Institutions and Money 21(3): 307-327.

Durand, P. 2019. Determinants of Banks' Profitability: Do Basel III Liquidity and Capital Ratios Matter? EconomiX - CNRS, working paper No. 2019-24, University of Paris Nanterre, France.

Eccles, R. 1991. The Performance Measurement Manifesto. Harvard Business Review 69(1), 131-137.

England, C. 1991. Are Banks Special? Regulation - The Cato Review of Busines \& Government (Spring): 25-34.

Flannery, M., \& K. Rangan. 2008. What Caused the Bank Capital Build-up of the 1990s? Review of Finance 12(2): 391-429.

Fraser, I. \& P. Monimer-Lee. 1993. The EC Single Market in Financial Services. Bank of England Quarterly Bulletin (February): 92-97.

Freixas, X. \& J.-C. Rochet. 2008. Microeconomics of Banking, $2^{\text {nd }}$ Ed. The MIT Press, Cambridge (MA), USA.

Fries, S., D. Neven \& P. Seabright. 2002. Bank Performance in Transition Economies. University of Michigan William Davidson Working Paper No. 505.

Frömmel, M. \& R. Kruse. 2015. Interest Rate Convergence in the EMS Prior to European Monetary Union. Journal of Policy Modeling 37: 990-1004.

Furlong, F. \& M. Keeley. 1989. Capital Regulation and Bank Risk-taking: A Note. Journal of Banking and Finance 13(6): 883-891.

García-Herrero, A., S. Gavilá \& D. Santabárbara. 2009. What Explains the Low Profitability of Chinese Banks? Journal of Banking \& Finance 33(11): 2080-2092.

Goddard, J., P. Molyneux \& J. Wilson. 2010. Banking in the European Union. In Berger, A., P. Molyneux \& J. Wilson, Editors. The Oxford Handbook of Banking, Chapter 32: 807-843. Oxford University Press, New York (NY), USA.

Goddard, J., P. Molyneux \& J. Wilson. 2004a. The Profitability of European Banks: A Cross-Sectional and Dynamic Panel Analysis. The Manchester School 72(3): 363-381.

Goddard, J., P. Molyneux \& J. Wilson. 2004b. Dynamics of Growth and Profitability in Banking. Journal of Money, Credit and Banking 36(6): 1069-1090.

Goldberg, L. G., \& A. Rai. 1996. The Structure-Performance Relationship for European Banking. Journal of Banking \& Finance 20(4): 745-771.

Greenbaum, S., A. Thakor \& A. Boot. 2016. Bank Capital Structure. In Contemporary Financial Intermediation, 3rd Ed., Chapter 13, 317-327. Elsevier, Amsterdam, Netherlands.

Gropp, R. \& F. Heider. 2010. The Determinants of Bank Capital Structure. Review of Finance 14(4): 587622.

Hannan; T. 1991. Foundations of the Structure-Conduct-Performance Paradigm in Banking. Journal of Money, Credit and Banking 23(1): 68-84.

Hannan, T. \& G. Hanweck. 1988. Bank Insolvency Risk and the Market for Large Certificates of Deposit. 
Journal of Money, Credit and Banking 20(2): 203-211.

Harker, P. \& S. Zenios. 2000. What Drives the Performance of Financial Institutions? In P. Harker \& S. Zenios, Editors. Performance of Financial Institutions, Chapter 1: 3-31. Cambridge University Press.

Higgins, R. 1977. How Much Growth Can a Firm Afford? Financial Management 6(3): 7-16.

Hughes, J. \& L. Mester. 2010. Efficiency in Banking: Theory, Practice, and Evidence. In Berger, A., P. Molyneux \& J. Wilson, Editors. The Oxford Handbook of Banking, Chapter 18: 463-485. Oxford University Press, New York (NY), USA.

John, K., T. John \& L. Senbet. 1991. Risk-Shifting Incentives of Depository Institutions: A New Perspective on Federal Deposit Insurance Reform. Journal of Banking and Finance 15(4-5): 895-915.

Jones, D. 2000. Emerging Problems with the Basel Capital Accord: Regulatory Capital Arbitrage and Related Issues. Journal of Banking and Finance 24(1-2): 35-58.

Kale, J., T. Noe \& G. Ramirez. 1991. The Effect of Business Risk on Corporate Capital Structure: Theory and Evidence. Journal of Finance 46(5): 1693-1715.

Kennerley, M. \& A. Neely. 2003. Measuring Performance in a Changing Business Environment. International Journal of Operations \& Production Management 23(2): 213-229.

Kim, D. \& A. Santomero. 1988. Risk in Banking and Capital Regulation. Journal of Finance 43(5): 12191233 .

Kwan, S. \& R. Eisenbeis. 1997. Bank Risk, Capitalization, and Operating Efficiency. Journal of Financial Services Research 12(2-3): 117-131.

Loukoianova, E. 2008. Analysis of the Efficiency and Profitability of the Japanese Banking System. IMF Working Paper No. WP/o8/63.

Lozano-Vivas, A., J. Pastor \& I. Hasan. 2001. European Bank Performance Beyond Country Borders: What Really Matters? European Finance Review 5(1-2): 141-165.

Lucas, D. \& R. McDonald. 1992. Bank Financing and Investment Decisions with Asymmetric Information about Loan Quality. The RAND Journal of Economics 23(1): 86-105.

Martins, F. \& M. Ribeiro. 2013. A Análise da Eficiência no Setor Bancário: Modelo de Fronteira Estocástica com Dados em Painel para a Banca Portuguesa. Nova Economia 23(3): 555-577.

Meh, C. \& K. Moran. 2010. The Role of Bank Capital in the Propagation of Shocks. Journal of Economic Dynamics and Control 34(3): 555-576.

Mendes, V. \& J. Rebelo. 2003. Structure and Performance in the Portuguese Banking Industry in the Nineties. Portuguese Economic Journal 2(1): 53-68.

Mendes, V. 1991. Scale and Scope Economies in Portuguese Commercial Banking: The Years 1965-88. Economia 15(3): 453-490.

Merton, R. 1995. A Functional Perspective of Financial Intermediation. Financial Management 24(2): 23-41.

Merton, R. 1977. An Analytic Derivation of the Cost of Deposit Insurance and Loan Guarantees. Journal of Banking and Finance 1: 3-11.

Mester, L. 2008. Optimal Industrial Structure in Banking. In A. Thakor \& A. Boot, Editors. Handbook of Financial Intermediation and Banking, Chapter 5: 133-162. Elsevier, Amsterdam, Netherlands.

Milney, A. \& A. Whalley. 2001. Bank Capital Regulation and Incentives for Risk-Taking. Cass Business School Research Paper.

Molyneux, P. \& J. Thornton. 1992. Determinants of European Bank Profitability: A Note. Journal of Banking and Finance 16(6): 1173-1178.

Molyneux, P. \& W. Forbes. 1995. Market Structure and Performance in European Banking. Applied Economics 27(2): 155-159.

Molyneux, P., Y. Altunbas \& E. Gardener. 1996. Efficiency in European Banking. In Efficiency in European Banking, Chapter 9: 252-304. John Wiley \& Sons, Chichester, UK.

Murphy, N. 2000. European Union Financial Developments: The Single Market, the Single Currency, and Banking. FDIC Banking Review 13(1): 1-18.

Neely, A., C. Adams \& M. Kennerley. 2002. The Performance Prism. Prentice Hall, London, UK.

Neely, A., M. Kennerley \& C. Adams. 2007. Performance Measurement Frameworks: A Review. In A. Neely, editor, Business Performance Measurement: Unifying Theories and Integrating Practice, $2^{\text {nd }}$ Ed., Chapter 7: 143-162. Cambridge University Press, Cambridge, UK.

Neuberger, D. 1998. Industrial Organization of Banking: A Review. International Journal of the Economics of Business 5(1): 97-118.

Neuberger, D. 1997. Structure, Conduct and Performance in Banking Markets. Thuenen-Series of Applied Economic Theory 12, University of Rostock, Institute of Economics.

Nikolaou, K. 2009. Liquidity (Risk) Concepts Definitions and Interactions. European Central Bank working paper series No. 1008.

Nogueira Leite, A. \& P. Pinho 1994. Conduct and Competition in Portuguese Commercial Banking. Faculdade de Economia Working Paper No. 216. Lisboa: Universidade Nova de Lisboa.

OECD. 2001, 2003, 2005, 2008, 2011. Bank Profitability: Financial Statements of Banks. OECD Banking Statistics, OECD Publishing.

OECD. 2011. OECD Banking Statistics: Methodological Country Notes. OECD Publishing. DOI: http://dx.doi.org/10.1787/9789264089907-en.

OECD. 2012. OECD Banking Statistics: Financial Statements of Banks. 
Oino, I. 2018. Impact of Regulatory Capital on European Banks Financial Performance: A Review of Post Global Financial Crisis. Research in International Business and Finance 44: 309-318.

Olson, M. 2006. Are Banks Still Special? BIS Review 20: 1-4; Remarks at the Annual Washington Conference of the Institute of International Bankers, Washington, DC, 13 March 2006.

Osborne, M., A.-M. Fuertes \& A. Milne. 2012. Capital and Profitability in Banking: Evidence from US Banks. Cass Business School, City University, London.

Otley, D. 2007. Accounting Performance Measurement: A Review of its Purposes and Practices. In A. Neely, Editor. Business Performance Measurement: Unifying Theories and Integrating Practice, $2^{\text {nd }}$ Ed., Chapter 1: 11-162. Cambridge University Press, Cambridge, UK.

Osterberg, W. \& J. Thomson. 1996. Optimal Financial Structure and Bank Capital Requirements: An Empirical Investigation. Journal of Financial Services Research 10(4): 315-332.

Pasiouras, F. \& K. Kosmidou. 2007. Factors Influencing the Profitability of Domestic and Foreign Commercial Banks in the European Union. Research in International Business and Finance 21(2): 222237.

Petria, N., B. Capraru \& I. Ihnatov. 2015. Determinants of Banks' Profitability: Evidence from EU 27 Banking Systems. Procedia Economics and Finance 20: 518-524.

Pinho, P. 2001. Using Accounting Data to Measure Efficiency in Banking: An Application to Portugal. Applied Financial Economics 11(5): 527-538.

Portela, M. \& E. Thanassoulis. 2007. Comparative Efficiency Analysis of Portuguese Bank Branches. European Journal of Operational Research 177(2): 1275-1288.

Psillaki, M. \& N. Daskalakis. 2009. Are the Determinants of Capital Structure Country or Firm Specific? Small Business Economics 33:319-333.

Repullo, R. \& J. Suarez. 2013. The Procyclical Effects of Bank Capital Regulation. Review of Financial Studies 26(2): 452-490.

Resti, A. 1997. Evaluating the Cost-efficiency of the Italian Banking System: What Can Be Learned from the Joint Application of Parametric and Non-parametric Techniques. Journal of Banking and Finance 21(2): 221-250.

Saunders, A. \& M. Cornett. 2007. Financial Institutions Management, $6^{\text {th }}$ Ed. McGraw-Hill, New York (NY), USA.

Scherer, F., D. Ross. 1990. Industrial Market Structure and Economic Performance. Houghton Mifflin Company, Boston (MA), USA.

Schoenmaker, D. \& T. Peek. 2014. The State of the Banking Sector in Europe. OECD Economics Department Working Paper No. 1102.

Scholes, M., P. Wilson \& M. Wolfson. 1990. Tax Planning, Regulatory Capital Planning, and Financial Reporting Strategy for Commercial Banks. Review of Financial Studies 3(4): 625-650.

Seabright, P., S. Fries, \& D. Neven. 2002. Bank Performance in Transition Economies. SSRN Electronic Journal; DOI: http://dx.doi.org/10.2139/ssrn.353180.

Valério, N., Editor. 2010. History of the Portuguese Banking System - From the Bank of Portugal's Role as a Central Bank to the European Monetary Union - 1831-1998, Vol. II. Banco de Portugal, Lisbon, Portugal.

Vasiliou, D. \& J. Karkazis. 2002. The Sustainable Growth Model in Banking: An Application to the National Bank of Greece. Managerial Finance 28(5): 20-26.

Wall, L. \& P. Peterson. 1996. Banks' Responses to Binding Regulatory Capital Requirements. Federal Reserve Bank of Atlanta Economic Review (March/April): 1-17. 
Year

\section{Appendix I | Milestones of the Portuguese Financial System's Regulatory Reform} Summary

$1975 \cdot$ Portuguese privately-owned banks were nationalized.

1977 • Portugal joined an International Monetary Fund (IMF) financial assistance program.

1983 - Portugal joined an IMF financial assistance program

1984 - Private investment and ownership in banking were legalized.

$1985 \cdot$ Mutual funds and fund management rules were approved.

- Treasury Bills were created.

- Interest rates were liberalized: minimum rates were set for over 180-day term deposits, and maximum rates

were set for 90 to 180 days, and over 2 years banking credit.

- Regulation of Pension Funds and Pension Funds management.

- The foreign exchange spot market was introduced.

1986 - Portugal joined the European Economic Community (EEC).

- The charter of Banco de Portugal (BdP) was revised.

-Venture capital was regulated.

- Money market brokers were allowed to establish and operate in the interbank market.

- The privatization of state-owned banks was made legally possible.

- Banks were allowed to invest in international money markets.

$1987 \cdot$ Certificates of Deposit were created.

- Rules and regulations for the Interbank securities market were changed to allow BdP to absorb excess liquidity, and introduce an open market policy.

- The exchange rate is no longer established by BdP. The Foreign Exchange market was liberalized. Operations in the forward exchange market started, although they were restricted to Portuguese legally resident banks.

- New security markets regulations were introduced. A securities exchange Auditor was appointed. Later, the securities exchange Auditor was replaced by a Securities Exchange Commission.

- Issuance of fixed-rate treasury bonds was launched and started to be traded in secondary market.

1988 - Introduction of revolving credit facilities to the public sector (CLIPs).

- Major changes related to the modernization of the security markets were introduced, including bonds with warrants; dematerialized equity securities; regulation of Initial Public Offerings and Public Offers of Acquisition; closed-end funds.

- Interbank money market brokers were allowed to operate in the Foreign Exchange Market.

- Banks are allowed to own brokerage and dealing houses.

- Limits on banking credit rates were fully removed.

$1989 \cdot$ A new minimum limit for banks' equity capital was established.

- The bank privatization program was initiated.

- The ceiling on check deposits was raised to one third of the minimum rate on term deposits under 180 days.

$1990 \cdot$ Limits on banking credit were fully eliminated

- A privatization law was passed, allowing the privatization, at the most, of 49 percent of formerly nationalized equity capital.

- Investment in foreign securities markets was allowed.

- The Portuguese Escudo starts to be monitored against the currencies of the Exchange Rate Mechanism (ERM)

- The definition, enforcement and oversight of banking accounting standards were assigned to BdP.

- Non-residents were allowed to buy foreign currency in the forward exchange market. Restrictions on the selling of foreign exchange against escudos to residents were kept in place.

- Banking capital adequacy requirements were introduced.

1991 - Leasing industry was authorized to expand into real estate.

- Foreign Exchange market was regulated.

- Brokers and dealers were allowed to offer securities custody services.

- The securities exchange code was approved.

- Transitory fiscal benefits were established to foster the development of the Securities Exchanges.

- The Securities Exchange Commission and its internal regulations were formally approved.

$1992 \cdot$ The EEC Directive No. 86/635/CEE, including accounting consolidation principles, and rules for financial

institutions, was transposed to the Portuguese legal system.

- The Portuguese currency joined the ERM of the European Monetary Union.

- Bank's deposit rates were liberalized.

- Control of capital movements was eliminated.

- Commercial paper issuance was regulated.

1993 - Introduction of new trading rules into the interbank money market.

1996 -The bank privatization program was concluded.

1999 Portugal joined the third phase of the Economic and Monetary Union (EMU).

2008 - The Legal Framework of Credit Institutions and Financial Companies was revised.

2011 Portugal joined an IMF/ European Central Bank / European Union Commission financial assistance program.

2014 Portugal leaves the IMF/ European Central Bank / European Union Commission financial assistance program.

Source: Adapted from Coutinho dos Santos $(2016$, p.) 


\section{Appendix II | Chronogram of the reprivatization of Portuguese banks}

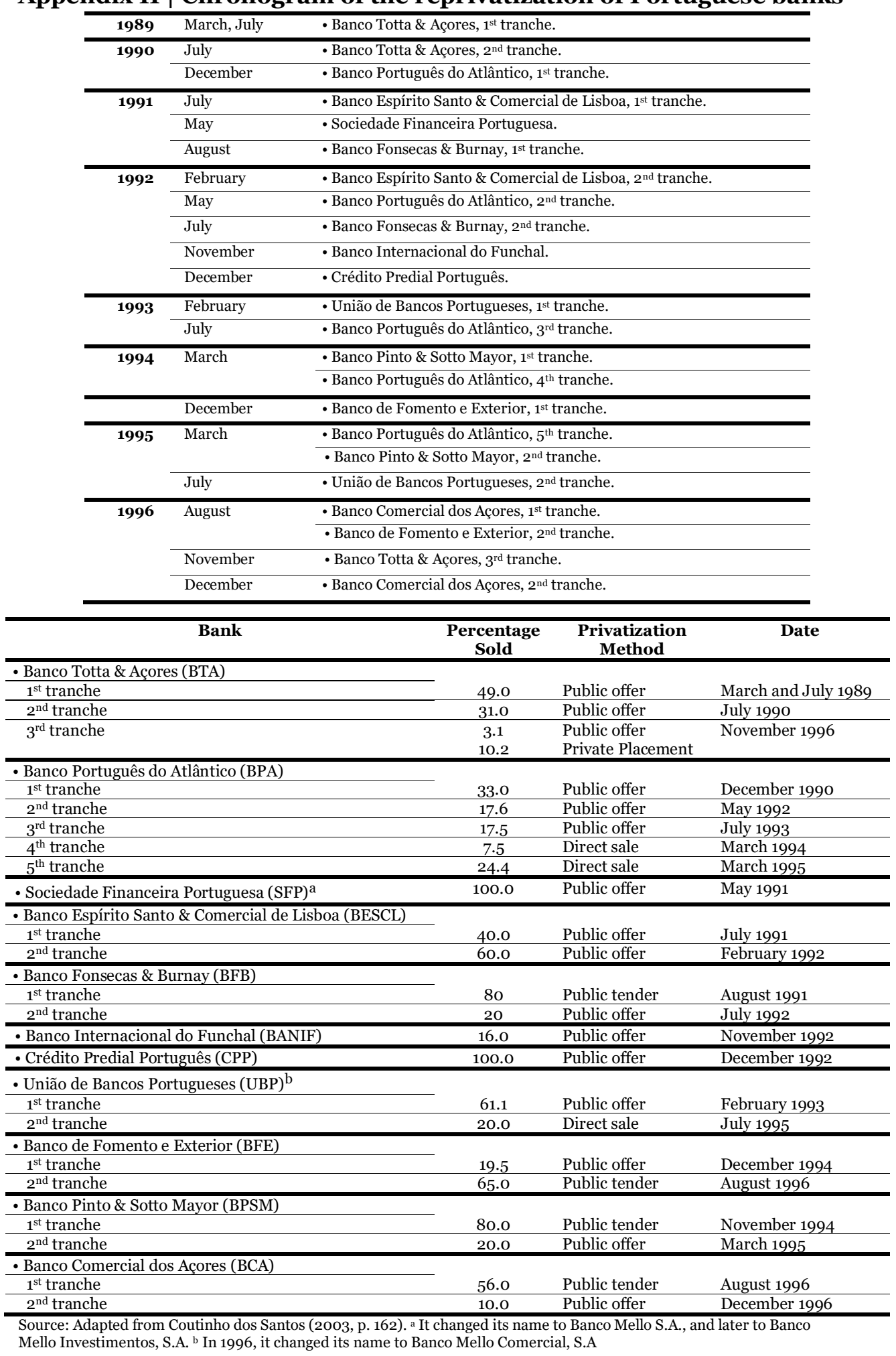




\section{Appendix III | Sample, Scope, Data availability and Missing data}

\begin{tabular}{|c|c|c|c|}
\hline Country & Scope & $\begin{array}{l}\text { Data } \\
\text { availability }\end{array}$ & Missing data \\
\hline Austria & All banks & 1994-2008 & $\begin{array}{l}\text { For the capital regulatory ratio variables in } \\
1993 .\end{array}$ \\
\hline Belgium & All banks & 1993-2009 & \\
\hline Finland & All banks & & $\begin{array}{l}\text { (i) For the capital regulatory ratio variables } \\
\text { from } 1993 \text { to 2009; and (ii) from } 1993 \text { to } \\
1998 \text { 'Net Provisions' were used instead of } \\
\text { Provisions on loans. }\end{array}$ \\
\hline France & All banks & & $\begin{array}{l}\text { (i) For the capital regulatory ratio variables } \\
\text { from } 1993 \text { to } 2009 \text {; (ii) For Staff Costs and } \\
\text { Other Operating Expenses from } 2000 \text { to } \\
\text { 2009; and (iii) From } 1993 \text { to } 2009 \text { Net } \\
\text { Provisions were used instead of Provisions } \\
\text { on loans. }\end{array}$ \\
\hline Germany & All banks & & $\begin{array}{l}\text { For the capital regulatory ratio variables } \\
\text { from } 1993 \text { to } 2009 \text {. }\end{array}$ \\
\hline Greece & Commercial banks & & $\begin{array}{l}\text { For the capital regulatory ratio variables } \\
\text { from } 1993 \text { to } 1995 \text {. }\end{array}$ \\
\hline Ireland & All banks & $1995^{-2009}$ & \\
\hline Italy & All banks & & \\
\hline Luxembourg & All banks & $1993-2008$ & $\begin{array}{l}\text { From } 1993 \text { to } 2009 \text { Net Provisions were } \\
\text { used instead of Provisions on loans. }\end{array}$ \\
\hline Netherlands & All banks & & \\
\hline Portugal & Commercial banks & & \\
\hline Spain & All banks & & $\begin{array}{l}\text { For the capital regulatory ratio variables } \\
\text { from } 1993 \text { to } 1998 \text {. }\end{array}$ \\
\hline
\end{tabular}

